ТЕТЯНА РАВЧИНА, кандидат педагогічних наук, дочент, кафедра загальної педагогіки та педагогіки вищої иколи,Львівський університет імені Івана Франка, заступник директора з навчальної роботи, ВСП технічний коледж НУ "Львівська політехніка", Україна tanya_ravchyna@yahoo.com

\title{
КОНЦЕПТУАЛЬНІ ЗАСАДИ ПЕДАГОГІЧНОЇ ПІДГОТОВКИ ВИКЛАДАЧА ВИЩОЇ ШКОЛИ В КОНТЕКСТІ СУЧАСНИХ ОСВІТНІХ ВИКЛИКІВ
}

\author{
TETYANA RAVCHYNA, Candidate of Pedagogical Sciences, Associate \\ Professor, Department of General Pedagogy and Pedagogy of \\ Higher School, Ivan Franko National University of Lviv, Deputy \\ Director of Educational Work, Technical College - Branch \\ Structural Unit of Lviv Polytechnic National University, Ukraine
}

\section{CONCEPTUAL FOUNDATIONS OF PEDAGOGICAL TRAINING A HIGHER SCHOOL TEACHER IN THE CONTEXT OF MODERN EDUCATIONAL CHALLENGES}

\begin{abstract}
У статті розглянуто суть та особливості студентоцентрованої концепції як методологічного підгрунтя організації освітнього процесу в контексті педагогічної підготовки майбутніх викладачів; виокремлено принципи навчання за цим підходом. Окреслено концептуальні ідеї студентоцентрованого підходу: організація освітнього процесу як когнітивної діяльності студентів засобами когнітивних стратегій та метапізнання, подання змісту вищої освіти у професійному, соціальному контекстах шляхом застосування автентичних джерел і автентичної діяльності, організація освітнього процесу на засадах суб'єкт-суб'єктної взаємодії викладача і студентів на засадах діалогу.
\end{abstract}

Ключові слова: педагогічна діяльність, педагогічна підготовка, освітній процес, педагогічна позиція, студентоцентрований підхід, когнітивна діяльність, автентичний контекст, суб'єкт-суб'єктна взаємодія, діалог.

Summary. On the basis of analyzing the problems of the higher school teacher's pedagogical activity through the eyes of higher education postgraduate students the article surveys the essence and peculiarities of the student-centered conception as the methodological basis of organizing the educational process in the context of pedagogical training the prospective

(C) Т. Равчина higher school teachers; it highlights the principles of education in terms of this approach. The author outlines the conceptual ideas of the studentcentered approach: organizing the educational process as the cognitive activity of students by means of cognitive strategies and metacognition, presenting higher education content in professional and social contexts by using the authentic sources and activity, organizing the educational process on the basis of subject-subject interaction of higher school teacher and students based on a dialogue.

Key words: pedagogical activity, pedagogical training, educational process, teacher's attitude, studentcentered approach, cognitive activity, authentic context, subject-subject interaction, dialogue.

Мета: обгрунтувати концептуальні ідеї, головні умови організації ефективного освітнього процесу, спрямованого на підготовку викладача вищої школи в контексті сучасних європейських тенденцій.

Постановка проблеми в загальному вигляді. Одним із стратегічних напрямів реформування і модернізації вищої освіти в Україні відповідно до освітніх викликів в умовах євроінтеграційних процесів, а також мінливості ринкової економіки $\epsilon$ формування фахівців європейського рівня, котрі визначаються професіоналізмом, критичністю і креативністю, конкурентоспроможні, активні у громадському житті, здатні свідомо адаптуватися до потреб ринку й виконувати складні соціальні, виробничі, економічні завдання. Досягнути конструктивних змін у системі вищої освіти неможливо без компетентної діяльності викладача, його самосвідомості, педагогічної і громадянської позиції. Однак, як засвідчує практика, деякі викладачі заперечують особливу значущість педагогічної підготовки для роботи у вищій школі порівняно із середньою освітою та вважають, що саме високий науковий рівень педагогічної діяльності становить визначальну умову підготовки компетентних фахівців у системі вищої освіти. Найвагоміший аргумент, що спростовує таке твердження, - це належність діяльності викладача до педагогічної професії, що визначається своєрідною специфікою та охоплює низку функцій окрім інформаційної (навчальну, гностичну, проєктивну, організаційну, проєктивну тощо).

Аналіз досліджень і публікацій. Напрями модернізації освітнього процесу відповідно до сучасних освітніх викликів досліджують В. Андрущенко, Я. Болюбаш, С. Гончаров, Н. Дворнікова, В. Журавський, М. Згуровський, В. Кремень, М. Степко. Питання підготовки викладача вищої освіти, забезпечення його професійно-педагогічного розвитку досліджено у працях С. Вітвицької, О. Вознюка, О. Гури, О. Дубасенюк, Н. Кузьм- 
іної, І. Ярмоли.

Виклад основного матеріалу дослідження. Головна функція діяльності викладача вищої школи в контексті сучасних освітніх трансформацій - це забезпечення належного рівня підготовки майбутніх фахівців відповідно до вимог державного освітнього стандарту, досягнення кількісних і якісних змін у їхньому професійному та особистісному розвитку. Ініціальна активність викладача виявляється у продуманій, цілеспрямованій організації у взаємозв'язку кожного етапу освітнього процесу, під час якого він залучає студентів до активної участі як рівноправних суб'єктів і підтримує їхню активну позицію.

У сучасній вищій школі існує стереотипна думка про достатність належного наукового і фахового рівнів для ефективної організації викладачем педагогічної діяльності. Як зазначає російський психолог Л. Виготський, від педагога завжди вимагали знання лише свого предмета, програми. Проте, педагогіка стає справжнім складним мистецтвом, що виникає на науковому підгрунті. Отож від педагога вимагаються підвищене знання предмета і техніки своєї справи (Выготский \& Давыдов, 2008, с. 392). У цьому контексті діяльність викладача вищої школи $\epsilon$ професійно педагогічною, зміст якої охоплює цілеспрямоване управління освітнім і виробничим процесами майбутніх фахівців, узгодження теорії і практики, що сприяє розвитку їхньої особистості та професійної індивідуальності. Професійна складова діяльності викладача передбачає систему знань, умінь та здібностей, що забезпечують професійну компетентність діяльності педагога, науковця і фахівця. Педагогічна спрямованість виявляється у сукупності знань, умінь, здібностей, позитивних мотивів діяльності й особистісних рис викладача, що необхідні для організації педагогічного впливу на розвиток майбутніх фахівців в освітньому процесі в закладі вищої освіти (Шарипов, 2012, c. 373, 378).

У досліджуваній літературі зазначено, що викладачі закладів вищої освіти не проходять належної спеціальної педагогічної підготовки порівняно з учителем середньої школи, що впливає на розвиток їхньої педагогічної майстерності, умінь аналізу педагогічних ситуацій та прийняття швидких доцільних рішень (Курлянд,
Хмелюк, \& Семенова, 2005, с. 231). Щорічне опитування аспірантів Львівського університету, котрі вивчають курс "Педагогіка вищої школи", дає змогу виокремити суперечності, що характерні для сучасної вищої школи та потребують нагального вирішення.

На основі узагальнення результатів опитування зазначимо загальні проблеми педагогічної діяльності у вищій школі через призму бачення молодих викладачів відповідно до структурних складових освітнього процесу (мети, змісту, організації освітнього процесу, взаємин викладача і студентів, поведінки викладача, оцінювання успіхів студентів):

- орієнтування викладача на подання змісту й оцінювання знань студентів;

- схоластичність змісту навчальних курсів, розрив теорії з практикою;

- домінування ролі викладача в освітньому процесі та репродуктивних методів навчання;

- відсутність належного контакту викладача зі студентами, перевага авторитарного стилю взаємин;

- організація порядку як нав'язування вимог студентам без досягнення домовленості з ними;

- суб'єктивність оцінювання викладачем результатів навчально-пізнавальної діяльності студентів.

Як засвідчують результати опитування, аспірантам цікаво знати, що становить мету педагогічної діяльності - організація процесу навчально-пізнавальної діяльності, формування знань, умінь студентів чи оцінювання результатів їхнього навчання. На їхню думку, сучасний зміст навчального матеріалу 3 деяких курсів застарілий, не відповідає сучасним досягненням науки, перенасичений теоретичною інформацією та віддалений від практики, майбутньої професійної діяльності студентів. Аспіранти також вважають, що деякі викладачі не пов'язують наукову інформацію з життєвим досвідом студентів, їхньою професією, а також базовими знаннями. Щодо організації процесу навчання вони зазначають, що студенти бажають співпрацювати 3 викладачем і потребують сучасних методів навчання. Молоді викладачі переконані, що студентів часто завантажують безглуздою роботою і не залучають до самостійного пошуку нової інформації або вирішення проблем. На переконання респондентів, педагог повинен залу- чати студентів до процесу навчання, стимулювати їх пізнавальну активність, давати змогу висловлювати свою думку й позицію.

Значної уваги аспіранти надають взаєминам педагога і здобувачів вищої освіти та вважають, що деякі викладачі зверхні й неконтактні, отож неспроможні налагодити взаємозв'язок зі студентами, переоцінюють роль субординації у педагогічній взаємодії. Вони наголошують на значенні мотивації діяльності викладача як вагомої умови організації ефективної педагогічної взаємодії. Аспіранти зазначають, що деякі викладачі працюють у вищій школі, тому що це престижно або щоб працювати, або реалізувати свою владу як педагог. Водночас вони вважають, що головними мотивами педагогічної діяльності повинні бути захопленість викладача наукою, інтерес до навчального курсу, бажання захопити студентів процесом пізнання, скерувати їх у напрямі оволодіння наукою, фахом i допомогти їм досягнути успіху. Аспіранти виокремлюють роль самовиховання викладача для успішної організації освітнього процесу, а також налагодження позитивних, довірливих взаємин. Поведінку викладача вищої школи вони розглядають 3 позицій педагогічної етики. Відстоюють думку, що викладач зобов'язаний контролювати за порядком в аудиторії, але не шляхом покарань за порушення студентами поведінки, а за допомогою застосування різних прийомів педагогічного впливу на їхні дії та вчинки. Аспіранти водночас наполягають на тому, що сучасний викладач повинен володіти прийомами конструктивного розв'язання конфліктів як зі студентами, так і $з$ іншими колегами. Найсерйознішою проблемою у вищій школі вони вважають суб'єктивність, несправедливість та упередженість оцінювання результатів навчання студентів без наведення конкретних аргументів.

Окреслені проблеми педагогічної діяльності у вищій школі засвідчують необхідність цілеспрямованої організації педагогічної підготовки викладача.

Головним показником оцінки результативності педагогічної підготовки викладача у вищій школі розглядають готовність випускників до педагогічної діяльності, якуінтерпретують як цілісне інтегроване утворення особистості у єдності особистісної та процесуальної складових (Курлянд, 
Хмелюк \& Семенова, 2005, с. 224230). Аналіз структури і змістового наповнення цієї інтегрованої властивості дає змогу виокремлювати в системі педагогічної підготовки викладачів вищої школи два взаємопов'язаних аспекти: професійний, що охоплює систему педагогічних компетентностей формування у майбутніх фахівців професійних знань й умінь, та педагогічний, що означає особистісне ставлення до педагогічної діяльності, суб'єктів процесу, здатність організовувати продуктивне освітнє середовище та партнерську, діалогічну взаємодію зі студентами, узгоджувати педагогічні впливи з їхніми індивідуальними особливостями, потребами та інтересами, а також цілеспрямовано самовдосконалюватися.

Організація освітнього процесу у вищій школі, досягнення його ефективності залежать переважно від педагогічної позиції викладача, його філософських установок, переконань. У педагогічній літературі зазначено, що саме переконання педагога мають більше значення для організації освітнього процесу, ніж його знання, уміння планувати і проводити навчальні заняття (Кнодель, 2008, c. 113). Особистісне бачення суті педагогічної діяльності, визначення власної місії, завдань та функцій студентів, розставлення пріоритетів у вищій освіті впливають на вибір та організацію викладачем кожного структурного елемента процесу (мети, стимулів, змісту, процесу навчально-пізнавальної діяльності студентів, зворотного зв'язку, оцінки одержаних результатів). Отже, у процесі педагогічної підготовки майбутніх викладачів слід орієнтувати на осмислення теоретико-методологічних засад організації освітнього процесуу вищій школі. Головно, що вони не лише повинні оволодіти сучасними концептуальними підходами, але й бути залучені до продуктивного освітнього середовища, що організоване на цих засадах, i бачити відповідні моделі педагогічної діяльності.

Підвалини філософії сучасної освіти становлять студентоцентрований центрований (феноменологічний, особистісно центрований) та конструктивістський підходи, що взаємопов'язані і взаємодоповнюють один одного. Студентоцентрований підхід розглядають як основоположний принцип європейського простору вищої освіти, що зміщує акценти 3 викладача (суб'єкта передачі знань) на процес навчання студента (суб'єкта освітньої діяльності) (Бульвінсь$\kappa a, 2018, c .24)$. Зазначена концепція передбачає розвиток вільної і творчої особистості, яка за власним бажанням та усвідомлено опановує нові знання й уміння, самостійно робить вибір і приймає рішення. У цьому контексті головна увага викладача вищої школи зосереджена на особистості студента, зокрема, його досвіді, стилі та напрямі мислення, від яких залежить процес пізнання нових понять, законів, теорій і набуття нових умінь. Студент стає рівноправним партнером викладача, а також активним суб'єктом освітнього процесу.

Конструктивістський підхід також центрований на студентові та наголошує, що кожна особистість у процесі навчально-пізнавальної діяльності самостійно конструює знання, творить суб'єктивний образ об'єктивної реальності шляхом пошуку власного розуміння, а саме надання особистісного сенсу наукової інформації. Остання стає значущою для особистості студента, тобто набуває сенсу для нього за умови поєднання ним нових ідей 3 набутим досвідом (Лефрансуа, 2005, с. 158). Згідно 3 таким підходом, що відповідає природі людського пізнання, знання не можна повністю передати студентам або відтворити, оскільки вони отримують їх у процесі пізнавальної діяльності.

За студентоцентрованим підходом змінюється соціальна роль, функції і позиція педагога в організації навчально-виховного процесу. Хоча його роль і надалі залишається вагомою, проте ставлення до різних складових і учасників цього процесу суттєво змінюється. Пріоритетне значення для викладача має не зміст навчального матеріалу, а організація різних видів навчально-пізнавальної діяльності, у процесі якої студенти як суб'єкти процесу взаємодіють 3 реальними об'єктами, досягають розуміння, доходять самостійних висновків, приймають рішення, набувають відповідного досвіду тощо. Основне для педагога - стимулювати й підтримувати розвиток мислення студентів, допомагати їм долати суперечності в пізнанні. Отож викладач відповідальний за організацію освітнього процесу, у якому студенти творять знання й особистісні цінності, набувають досвіду виконання різних видів діяльності та міжособистісної взаємодії $з$ педагогами, іншими колегами, а також розвиваються як суб'єкти освітнього процесу. Вагомим обов'язком викладача $є$ залучення кожної особистості до освітнього процесу, однак - не засобами примусу, а шляхом захоплення процеcom.

Згідно із студентоцентрованим підходом викладач як суб'єкт партнерської взаємодії зі студентами виконує різні ролі в освітньому процесі (менеджера, посередника, фасилітатора, коуча тощо) (Бульвінська, 2018 , с. 24). Як менеджер він приймає рішення щодо планування освітнього процесу, проєктування власної та активності студентів на кожному його етапі; організації та модифікації різних видів навчально-пізнавальної діяльності; рефлексії педагогічних дій та їхніх наслідків для діяльності студентів. Виконання інших ролей виявляється в організації процесу, у якому студенти мають змогу вільно й активно пізнавати, виробляти власне розуміння наукових теорій, особистісне бачення і вирішення професійних проблем тощо (Лефрансуа, 2005, c. 163; Cruickshank, Jenkins \& Metcalf, 2009, c. 269-272). Таким чином, викладач скеровує майбутніх фахівців до визначення мети навчально-пізнавальної діяльності на кожному іiї етапі; допомагає усвідомити суть, значущість змісту наукової інформації та розумових, практичних дій, які вони виконують; дає змогу вільно висловлювати власні думки та підтримує плюралізм суджень; орієнтує студентів на осмислення й оцінку досягнутих результатів, виконаних дій; забезпечує умови для їхнього позитивного самопочуття та одержання задоволення від змісту набутого і процесу; постійно погоджує зі студентами цілі, завдання та вимоги до навчально-пізнавальної діяльності, власні педагогічні дії. Саме за таких умов студенти стають цілком задіяними у навчанні та відчувають власну відповідальність за пізнавальну діяльність.

Для досягнення розуміння студентами наукових понять, теорій тощо вагоме значення у контексті студентоцентрованого підходу, зокрема конструктивістського, має організація освітнього процесу як когнітивної (розумової) діяльності. На думку науковців, для викладача вищої школи важливими $€$ не організація змісту наукової інформації, а залучення студентів до когнітивних (розумових) 
процесів, що забезпечують осмислене, саморегульоване оволодіння знаннями, визначення понять і набуття умінь. Тому цілеспрямоване оволодіння когнітивними стратегіями (процедурою, системою послідовних дій, таких як аналіз, організація, повторення, обробка одержаних фактів) дає змогу самостійно шукати власне розуміння об'єктивних явищ, робити висновки, систематизувати їх і свідомо творити знання (Лефрансуа, 2005, c. 146; Савчин, 2007, с. 232-233). Саме застосування когнітивних стратегій як інструментів інтелектуальної діяльності у процесі виконання різних видів діяльності сприяє виробленню студентами індивідуального стилю мислення, власної суб'єктної позиції в освітньому процесі. Навчальна діяльність набуває ефективності, якщо студенти усвідомлюють власний процес пізнання, аналізують й осмислюють когнітивні дії, що вони застосовують для розуміння сутності явища, тобто організовують процес метапізнання як одержання знань про власні когнітивні процеси (Лефрансуа, 2005, с. 146; Савчин, 2007, c. 232-233). Стимулювання їх до рефлексії власного процесу пізнання, а саме метапізнання, особистісних цінностей, ставлень $є$ своєрідним зворотним зв'язком, допомагає у регулюванні власної пізнавальної діяльності, а викладачеві - у модифікації методів, форм, видів навчальнопізнавальної діяльності, контролі самого процесу зв'язку відповідно до досягнень студентів, їхніх потреб, інтересів.

На процес набуття знань, умінь, досвіду, формування культури та цінностей студентів впливає організація змісту навчальних дисциплін у відповідному соціальному, професійному, практичному контекстах (Cruickshank, Jenkins \& Metcalf, 2009, c. 91). 3 цією метою викладач моделює автентичні (реальні, природні), професійні, життєві ситуації, у яких студенти прогнозують, приймають рішення щодо організації власних дій. Організація автентичної (природної) діяльності, у процесі якої вони виконують практичні дії, наближені до реального життя, також дає їм змогу визначити взаємозв'язки між науковою, навчальною інформацією та контекстом справжнього життя. На відміну від змісту, перевантаженому теоріями, науковою інформацією, такий підхід покращує розуміння суті наукової інформації та її значущості, наближує до майбутньої професійної діяльності, розвиває гнучкість мислення та глибину суджень, забезпечує вихід за межі стереотипів. Приміром, для забезпечення автентичного контексту у процесі педагогічної підготовки викладач залучає студентів до ознайомлення з історичними подіями, пов'язаними з розвитком шкільництва в Україні та зарубіжних країнах, поглядами освітян, педагогів, науковців шляхом вивчення відповідних архівних матеріалів, автентичних текстів, педагогічної спадщини, відвідування історичних місць, навчальних закладів тощо, а також спрямовує їх до аналізу реальних педагогічних ситуацій і кейсів, проєктування шляхів вирішення актуальних педагогічних проблем, виконання практичних завдань. До автентичних джерел, що варто застосовувати у процесі педагогічної підготовки, слід віднести також досвід і дослідження викладачів, студентів, науковців, спогади очевидців тощо.

Виходячи із систематизації зазначених вище ідей, виокремимо принципи студентоцентрованої концепції, що становлять методологічне підгрунтя організації освітнього процесу в контексті педагогічної підготовки майбутніх викладачів (Hertsyuk, Horuk \& Ravchyna, 2018, p. 196-198):

- навчання як суб'єкт-суб'єктна, партнерська взаємодія викладача i студентів;

•навчання як набуття студентами власного досвіду;

•єдність зовнішньої та внутрішньої активності студентів;

- відкритість і позитивна спрямованість навчання;

• контекстуальне й автентичне навчання;

- вільний вибір і прийняття рішень;

- рефлексія студентами власної діяльності й поведінки.

Згідно з концептуальними ідеями студентоцентрованого підходу освітній процес розглядають як організацію суб'єкт-суб'єктної взаємодії викладача і студентів на засадах рівноправних стосунків між ними й партнерства, у процесі якої викладач скеровує студентів, підтримує їх, надає їм змогу здійснювати самостійний вибір, відчувати власну відповідальність за діяльність. На противагу одноосібному або домінувальному чи нейтральному типові партнерська взаємодія проходить як взає- мне сприяння, підтримка один одного, що забезпечують взаєморозуміння між учасниками освітнього процесу, узгодження ними спільних дій, під час якої зміст навчальних курсів стає значущим для студентів. Налагодженню психологічного контакту викладача і студентів, що є запорукою їхньої партнерської взаємодії, сприяють: система добудов викладача для розвитку рівноправної взаємодії зі студентами; інтелектуальне й емоційне співпереживання партнерів; пошук спільного бачення проблеми; вияв поваги, емпатії, толерантності (Фрейре, 2003, с. 71-75). Підгрунтя партнерства викладача i студентів становить організація міжособистісної взаємодії як діалогу, взаємообміну інформацією та власним досвідом, спільного пошуку шляхів досягнення визначеної разом мети. Виокремимо провідні ознаки діалогічної взаємодії учасників освітнього процесу: відкритість до інноваційних змін кожної особистості, плюралізму думок тощо; забезпечення умов для свободи, автономності дій студентів, їхньої безпосередньої поведінки, різносторонньої активності, ініціативи; орієнтація на розвиток критичного і творчого мислення; наявність багатьох варіантів вибору; спрямованість педагога на майбутнє, позитивні очікування, перспективи розвитку студентів (Волкова, 2006, $c$. 31-34). 3 метою організації освітнього процесу на засадах діалогу викладач застосовує різноманітні засоби: систему цілеспрямованих, логічно пов'язаних запитань, що спонукають студентів до критичного мислення, особистісних оцінок; посилання на наукові дослідження, аргументи для спрямування у необхідному напрямі; безоцінні судження замість критичних оцінок чи засуджень; відгук на судження студентів замість реакцій, особливо негативного відтінку; позитивні ствердження для стимулювання студента до самостійного міркування; апелювання до думок, поглядів студентів; висловлювання від власного імені, демонстрування власних почуттів; спонукання до особистісної оцінки змісту і процесу навчання, висловлення власних оцінних суджень. Отож організація освітнього процесу як суб'єкт-суб'єктної взаємодії викладача і студентів на засадах діалогу забезпечує умови для реалізації провідних ідей студентоцентрованої концепції та надає змогу майбутнім фахівцям форму- 
вати самостійні судження, вправлятися у вільному міркуванні, шукати власне бачення об'єктів пізнання шляхом критичного осмислення, розвивати професійне мислення.

Висновки та перспективи подальших досліджень. Педагогічна підготовка викладача вищої школи в контексті сучасних викликів передбачає, насамперед, формування педагогічної позиції, що грунтується на знанні концептуальних засад вищої освіти, а також створення продуктивного освітнього середовища, організованого на цих засадах, що дає змогу майбутнім викладачам наслідувати відповідні моделі педагогічної діяльності. Основоположним концептуальним підходом до організації освітнього процесу у вищій школі є студентоцентрований підхід як основоположний принцип європейського простору вищої освіти. Відповідно студент стає активним суб'єктом освітнього процесу та рівноправним партнером викладача в освітньому процесі. Керівна роль викладача у вищій школі зберігається, однак, він перестає бути єдиним носієм інформації та стає відповідальним за організацію освітнього процесу, у якому студент має право на власну думку, самостійний вибір і прийняття рішень. Концептуальними ідеями студентоцентрованого навчання вважаємо: організацію освітнього процесу як когнітивної діяльності студентів засобами когнітивних стратегій та метапізнання, подання змісту вищої освіти у професійному, соціальному контекстах шляхом застосування автентичних джерел і автентичної діяльності, організація освітнього процесу на засадах суб'єкт-суб'єктної взаємодії викладача і студентів на засадах діалогу.

Подальші дослідження можуть бути зосереджені на аналізі й висвітленні шляхів реалізації концептуальних засад підготовки викладача в контексті сучасних освітніх викликів.

\section{СПИСОК ЛТТЕРАТУРИ}

Бульвінська, О. (2018). Сучасні тенденції безперервного професій- ного розвитку науково-педагогічних працівників закладів вищої освіти. Неперервна професійна освіта: теорія і практика, (1-2), 22-30. Взято 3 https://doi.org/10.28925/16098595.2018(1-2)2230.

Волкова, Н. П. (2006). Професійно-педагогічна комунікація. Київ : ВЦ "Академія". ISBN 966-580-216-X.

Выготский Л. С., \& Давыдов, В. В. (2008). Педагогическая психология. Москва : АСТ : Астрель : Хранитель.

Лефрансуа, Г. (2005). Прикладная педагогическая психология. СПб. : прайм ЕВРО-ЗНАК. ISBN 5-93878159-0.

Кнодель, Л. В. (2008). Педагогіка вищої школи. Київ : Вид. ПАЛИВОДА А.В. ISBN 978-966-437-043-8.

Курлянд, 3.Н., Хмелюк, Р. І., Семенова, А. В. (2005). Педагогіка вищої школи. Київ : Знання. ISBN 966-346270-1.

Савчин, М. В. (2007). Педагогічна психологія. Київ : Академвидав. ISBN 978-966-8226-51-9.

Фрейре, П. (2003). Педагогіка пригноблених. Київ : Юніверс. ISBN 9667305-68-6.

Шарипов, Ф. В. (2012). Педагогика и психология высшей школы. Москва : Логос. ISBN 978-5-98704-587-9.

Cruickshank, D. R., Jenkins, D. B., Metcalf, K. K. (2009). The act of teaching. New York: McGraw-Hill, Inc. ISBN-10: 0073378399.

Hertsyuk, D., Horuk, N., Ravchyna, T. (2018). Improving vocational education teacher training at Lviv University within the framework of the Erasmus+ Project ITE-VET. Improving teacher education for applied learning in the field of VET, 187-209. Waxmann Verlag GmbH. ISBN 978-38309-3960-3.

\section{REFERENCES}

Bulvinska, O. (2018). Suchasni tendentsii bezperervnoho profesiinoho rozvytku naukovo-pedahohichnykh pratsivnykiv zakladiv vyshchoi osvity. Neperervna profesiina osvita: teoriia i praktyka, (1-2), 22-30. Retrieved from https://doi.org/10.28925/16098595.2018(1-2)2230. (Modern trends of continuing professional development of academic staff in higher education institutions).

Volkova, N. P. (2006). Profesiinopedahohichna komunikatsiia. Kyiv : VTs "Akademiia". ISBN 966-580-216-X ( Profes s i on a l - ped a g og i ca 1 communication).

Vygotskii L. S., \& Davydov, V. V. (2008). Piedagogichieskaia psikhologiia. Moskva : AST : Astriel : Khranitiel. (Pedagogical psychology).

Lefransua, H. (2005). Prikladnaia piedagogichieskaia psikhologiia. $\mathrm{SPb}$. : praim IEVRO-ZNAK. ISBN 5-93878159-0. (Applied pedagogical psychology).

Knodel, L. V. (2008). Pedahohika vyshchoi shkoly: Posib. dlia mahistriv. Kyiv: Vyd. PALYVODAA.V. ISBN 978966-437-043-8. (Pedagogy of higher school).

Kurliand, Z. N., Khmeliuk, R. I., Semenova, A. V. (2005). Pedahohika vyshchoi shkoly. Kyiv : Znannia. ISBN 966-346-270-1. (Pedagogy of higher school).

Savchyn, M. V. (2007). Pedahohichna psykholohiia. Kyiv : Akademvydav. ISBN 978-966-8226-519. (Pedagogical psychology).

Freire, P. (2003). Pedahohika pryhnoblenykh. Kyiv: Yunivers. ISBN 966-7305-68-6. (Pedagogy of the oppressed).

Sharipov, F. V. (2012). Piedagogika i psikhologiia vysshei shkoly. Moskva : Logos. ISBN 978-5-98704-587-9. (Pedagogy and psychology of higher school).

Cruickshank, D. R., Jenkins, D. B., Metcalf, K. K. (2009). The act of teaching. New York: McGraw-Hill, Inc. ISBN-10: 0073378399.

Hertsyuk, D., Horuk, N., Ravchyna, T. (2018). Improving vocational education teacher training at Lviv University within the framework of the Erasmus+ Project ITE-VET. Improving teacher education for applied learning in the field of VET, 187-209. Waxmann Verlag GmbH. ISBN 978-38309-3960-3.

Стаття надійшла 28.03.2020 p. 